\title{
Plant Pathology and Ornamental Horticulture
}

\author{
Silvia Regina Galleti ${ }^{1}$
}

Ornamental plants, as well as other crops, are hostage to diseases caused by fungi, bacteria, viruses, and nematodes that can either cause small losses or be a limiting production factor. Facing a phytosanitary problem, the speed of diagnosis will be the differential of how much the disease can be disseminated within the crop.

In this context, research is done on the characterization of phytopathogens, as well as epidemiological studies and disease management, which are essential for a fast and accurate diagnosis. It is also noteworthy that the diagnosis of the disease allows producers to correctly control pathogens, avoiding errors and waste.

Also, if on the one hand, we have a growing flower and ornamental plant market, on the other we have the disordered growth in the production of these plants and the need to supply the market with innovations. As a result, many diseases and pests have emerged from both vegetable and fruit crops, as well as from ornamental plants brought from other countries, deserving the proper attention and dedication of phytopathologists.

Thus, the importance and the need for the dissemination of research results for the development of agribusiness in the field of ornamental horticulture are irrefutable. Let us make use of this important vehicle of scientific communication which is the Ornamental Horticulture. This journal is gaining its due prominence in the scenario of scientific publications, promoting visibility and impact of the research published in it, deserving to have in it the valuable collaboration of phytopathologists.

\section{References}

ALEXANDRE, M.A.V.; DUARTE, L.M.L.; CAMPOS, A.E.C. (coord.) Plantas ornamentais: Doenças e Pragas, 2ed. São Paulo: Devir, 2017. 600p.

REIS, S.N.; FERNANDES, K.D.; PAIVA, P.D.O.; SOUZA, P.E.; SOUZA, R.M. Levantamento de doenças em plantas ornamentais diagnosticadas na Clínica Fitossanitária da Universidade Federal de Lavras, Lavras/MG, no período de 2002 a 2006. Ornamental Horticulture, v.13, 2007 (Supplement).

RIVAS, E.B.; SAES, L.A. (coord.) Anais da XIV Reunião Itinerante de Fitossanidade do Instituto Biológico - Plantas Ornamentais. 2006. Available at: http://www.biologico.agricultura.sp.gov.br/page/ anais-da-rifib/xiv-reuniao-itinerante-de-fitossanidade-do-institutobiologico. Accessed on Dec 062019.

\footnotetext{
${ }^{1}$ 0000-0002-0745-5716 Instituto Biológico (APTA/SAA), São Paulo-SP, Brazil. galleti@biologico.sp.gov.br
} 